\title{
Possibilities for Motorways of the Sea development in the eastern part of the Adriatic Sea
}

\author{
Bojan Beškovnik, Ph.D. \\ Intereuropa, Global logistics service, Ltd. Co., Slovenija
}

\begin{abstract}

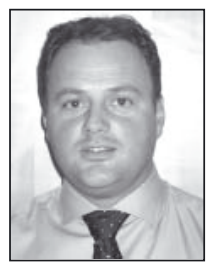

This article presents a wider perspective on possibilities of Motorways of the Sea development in the Adriatic Sea, with a special emphasis on the eastern coast of the Adriatic Sea. A complete overview of Motorways of the Sea development has been presented, and key elements influencing the development of Motorways of the Sea were analysed. It has been ascertained that there exist a lot of bottlenecks in the connection to the transport infrastructure in South East Europe. Superannuated port infrastructure, unsuitable inland connections, and nonexistent IT tools for electronic data exchange between all participators in the logistics chain hinder dynamic development of Motorways of the Sea. All these elements were thoroughly analysed, and a proposal for a macro transport strategy suitable for South East Europe has been exposed. It has been accentuated that there is a future for Motorways of the Sea introduction but all described bottlenecks have to be further analysed and removed in a short period of time, to stimulate private sector for financial investments.
\end{abstract}

Key words: Motorways of the Sea; port infrastructure; intermodality; inland connections; South East Europe; Adriatic Sea

\section{INTRODUCTION}

Today, intermodality and the use of sea transport route is an important topic of European transport policy. Consequently, these fields are subjects of detailed analysis and are included in the European development plans. Establishing intermodality and developing Motorways of the Sea to obtain sustainable passenger and cargo mobility are essential goals for the European Commission. Such a policy is not new, as it was developed in early nineties of last century, when a green paper on the impact of transport on the environment was released by the European Commission. In addition, a white paper on the common transport policy was presented in 1992, where the industry was called to support co-modality between different transport modes, especially between sea and rail transport, and to establish efficient transport services using intermodal nodes within the EU network.

The idea and the concept of MoS were firstly developed in June 1992 when Viamare S.p.A. introduced the first initiative to shift road transport to the sea. It was a sea line between Genoa and Termini Imersi in Sicily that was the starting point of today's common European strategy called Motorways of the Sea (MoS). According to Paixao [1], Bagchus and Kuipers [2] presented the concept "autostrade del mare" for the cargo shift from the road to the sea in the Portugal and Netherlands Corridor. This MoS concept started a dynamic development in
Europe, as Grimaldi introduced the service between Genoa and Palermo, and the International Association of Turkish hauliers introduced a RO-RO (roll on-roll off) service between Turkey and Italy. Different services were established in the next years, first a RoPax (roll on-roll off and passenger) service between Ancona and Patras, followed by different services in the Baltic and North Sea region.

Increased industrial interests stimulated the European Commission to highlight the $\mathrm{MoS}$ as a European concept to decrease the use of road transport, and consequently decrease the air pollution and traffic congestion in the European territory. Psaraftis [3] says that MoS will concentrate flows of freight on specific sea routes with the aim to establish new viable, regular and frequent maritime links between Member States, reduce road congestion, and improve the access to peripheral EU countries. For this reason the MoS concept has been promoted as an intra-community strategy and a cross-border project between all EU states. Special emphasis was put on ports with their infrastructure and hinterland connections, especially the railway network connections. European Commission recognised that MoS should be developed under a long-term transport strategy. Thus, different studies and project were launched and financially supported. Baird [4] recognises that from an academic standpoint these projects also contributed towards the development of an analytical framework to determine the feasibility of MoS. 
Some EU countries already developed MoS services for regular sailing from their ports. A big challenge is foreseen for the region of South East Europe, especially for the Adriatic Sea region. This was also recognised by previous research studies done by Haralambous [5] and Tilling [6]. Consequently, new research activities are necessary to stimulate the development of MoS in South East Europe and in the Adriatic Sea.

\section{THE MOS CONCEPT}

\section{Development of MoS in EU transport network}

The MoS were developed on a European Short Sea Shipping platform, as they are involving different operators and logistics players in a unique transport chain. The MoS concept was placed by EU as a strategic transport policy for the second time in 2001. Previously the European Commission worked on the 'European Marine Motorways' project under the Transport Research and Technological Development Program of the 4th Framework. Within this program, commercial viability of conventional and high-speed RO-RO services was studied in order to find an alternative to freight road transport.

With a white paper on transport policy presented by European Commission in 2001 some important principles regarding the implementation of $\mathrm{MoS}$ were incorporated into a strategic European document. The use of European inland waterways to support more balanced usage of transport modes and to develop intermodality placed a special focus on port organization and infrastructure in use. In addition, European Commission suggested that the industry prioritises ports with good hinterland rail connections and supports the creation of important intermodal points in the Mediterranean, Atlantic and North Sea coasts.

On this base, the study to define four MoS regions was carried out by the High Level Group, chaired by Karel van Miert and supported by European Commission [7]. According to the study presented in June 2003, the following four regions were proposed and later on accepted by the European Commission:

- Motorway of the Baltic Sea (linking the Baltic Sea with Central and Western Europe, including the route through the North Sea/Baltic Sea Canal);

- Motorway of the Sea of Western Europe (leading from Portugal and Spain via the Atlantic Arc to the North Sea and the Irish Sea);

- Motorway of the Sea of South East Europe (connecting the Adriatic Sea to the Ionian Sea and the Eastern Mediterranean, including Cyprus);

- Motorway of the Sea of South West Europe (western Mediterranean, connecting Spain, France, Italy, Malta and linking South East Europe and also the Black Sea).

According to the experience from the Short Sea Shipping development, a lot of bottlenecks were identified. These are: complicated customs procedures, a lot of paper work, different operational and commercial documents in use, administrative procedures, expensive services' implementation, mostly insufficient critical mass of cargo to be shifted in a short period, etc. During the last decade a lot of bottlenecks were eliminated, resulting in better starting conditions to establish and promote MoS. The European Commission played a crucial role in these actions, especially in reducing administrative barriers and in simplifying customs formalities on the entire transport route.

The major unsettled problems are still connected to the ports, their infrastructures and the railway networks, which are especially in eastern and southern Europe underdeveloped. Such infrastructure hardly supports cargo's expectation for fast and cost effective services. In addition, the economy in the region is underdeveloped. This was ascertained also by Midelfart-Knarvik et al. [8], as they say that the MoS of the Baltic Sea and the MoS of Western Europe offer greater potentials in MoS development; as they can be supported by higher industrial distribution at a European level and by better trade relations. Moreover, Paixao [1] says that not all ports will be MoS gateways, only $87.2 \%$ of port authorities surveyed in a research of EU ports are predisposed to become MoS interfaces.

\section{Key elements influencing development of MoS}

It is of crucial importance to identify key elements that influence the development of MoS, because they have a deep impact on strategic decisions of shippers and intermodal operators. Based on the analyse of the European Marine Motorways project (EMMA) under the $4^{\text {th }}$ Framework Program, Baird [9] exposes six main elements influencing adoption of $\mathrm{MoS}$ in EU transport framework. These elements are:

- Price - MoS transport price versus actual road transport;

- Service schedule - minimum service schedule of MoS should be a daily service to compete with actual road service;

- Reliability - regular departures of vessels, with no weather influences;

- Transit time - MoS should secure 24 to 48 hours door-todoor services to compete with actual road service;

- Efficiency in port - factors as handling speed, cargo security, 24-hour working in the port should be secured to maintain low-cost transport and service schedules;

- On-board facilities - a range of services for drivers should be secured to accompany the cargo and to be included in the total transport costs.

The price of transport services provided by MoS is a sensitive factor, because shippers or cargo owners might decide to shift their cargo from road transport to a MoS service, just in case the "all in" price is competitive. According to the United Kingdom Marine Motorways study performed by Napier University and Partners [10], a price of a RO-RO door-to-door service consists of the following three groups of costs:

- $\quad 50 \%$ for the sea RO-RO transport;

- $\quad 42 \%$ for road transport from door to port services and vice versa;

8\% for cargo handling.

From the MoS price perspective it has to be emphasised that the price of inland transport is still very crucial in total costs for $\mathrm{MoS}$ services. Even if we shift cargo from road to the sea, over $40 \%$ of all costs will be generated by inland services. Almost one tenth of all costs are produced by cargo handling. This poses very important pressure to the ports, in order to increase efficiency in every sphere of their organisation. Maintaining service schedule, service reliability and total door-to-door transit time are key elements to be secured by MoS. Shinghal and Fowkes [11] say that high frequency is a central attribute when customers are determining mode choice.

In addition to the above six key elements, three important factors should be also mentioned. The first one is the degree of the developed hinterland infrastructure. The second one is the location of port terminals or hinterland intermodal terminals, and the third one is an IT connection between all participators in the logistics chains. 
The efficiency of ports, port services and especially porthinterland connections are important elements for $\operatorname{MoS}$ [12]. The issue of developed or modernised hinterland infrastructure is for sure a big challenge for the underdeveloped regions and economies. Even if a super fast RO-RO service is introduced between the two ports, the problem of superannuated inland infrastructure can eliminate the advantage of fast sea service. The location of ports or hinterland intermodal terminals influences the transfer of cargo from different transport means. Ports or intermodal terminals must be positioned out of urban centres and massive traffic, to guarantee congestion-free access between sea and inland transport. Special transport corridors should be introduced to speed up the transfer of intermodal transport units out of the port or terminal systems. This must be supported by uniformed IT programs and connections, and by simplified documentation procedures.

Based on all described key elements influencing the development of MoS services in the European transport network it can be stressed out that intermodality plays a crucial role in MoS development. The MoS can be more easily introduced in the areas where intermodal transport is already present and frequently used. Paulauskas and Bentzen [13] accentuate that a few parallel and independent transport routes that exclude any negative technical, political or economical influence are needed to develop MoS. Moreover, IT platforms and IT tools between port authorities, port operators, financial institutions, cargo owners, logistics operators etc. should be uniformed to simplify logistics processes in the door-to-door cargo delivery.

For sure the financial perspective of supporting MoS development has to be considered too, as MoS implementation is directly connected to the financial support of the national economy of an interested state, or European founds. Of course, financial investments from the private sector are of significant importance, too. Beside this issue, the primary focus is on the infrastructure, which has to be previously secured. Only in this way will shippers and operators support the modal shift offered by MoS.

\section{TRANSPORT CHARACTERISTICS OF EAST MEDITERRAN AND ADRIATIC SEA}

The region of South East Europe is becoming very interesting research matter from the transport and logistics perspective. This is mainly connected with the analysed possibilities of further economical development and investment possibilities performed by global manufacturing and logistics companies. The region of Balkans is therefore presenting an opportunity to partly cover manufacturing necessities for the western economies, as in the era of global crisis transport costs have become an important issue of total price reduction. Far East production established in last decades is moving closer to the final consumer markets. Eastern Europe was recognized as an important alternative. These possibilities were already recognized by Fiat, Bosch, Continental, IKEA etc.

South East Europe is attracting developed economies, but investments in massive manufacturing need a support from the transport and logistics sector in order to ensure "just in time" and "just in sequence" production and distribution of products to the final consumers. Consequently, the development of transport infrastructure and new transport concepts will play a significant role in future development of the region.

Transport concepts like MoS can significantly support increased cargo flows of raw materials in import and finished product in export from the Balkans. The MoS will also fulfil higher transport quality expectations from the investors and logistics operators. Analysing the existing transport infrastructure and procedural bottlenecks can speed up the economy and industry to prioritise the settlement of the mentioned tasks.

\section{Analysing and removing existing bottlenecks}

Bottlenecks influencing the development of MoS in South East Europe were analysed in different research papers $[5,6$, 14, 15]. With the S.W.O.T analyse Haralambous [5] exposed six main weaknesses of MoS in South East Europe. These are:

- Inadequate port infrastructure to support intermodality in all states,

- Problematic port-hinterland connections, mainly with railway routes,

- Insufficient railway infrastructure in all parts, delay in the realisation of the TEN railway projects in South East Europe,

Over-aged vessel fleet shipping in the area, unable to support fast modal shift,

- Lack of synergy among states and economies,

- Absence of large Trans-national logistic operators that could play the leading role for uniting interested actors.

In addition, Haralambous [5] says that threats, such as congestion in core ports and lines, dependences of regional economies, mostly on road transport, and the risk of failure of viable schemes after the end of funding, due to high investment and operational costs, are influencing the development of MoS. Consequently, it can be stated that transport infrastructure and services directly related to it are presenting the main bottleneck.

Tilling [6] also sees the main bottleneck in the underdeveloped infrastructure and complete transport sector, and exposes that drastic reform in the transport industry is still advocated as the only chance of the survival and economic growth of the South East European countries, as the capacity of countries to maintain the existing infrastructure and operational services is practically non-existent.

Beside the superannuate infrastructure, an important bottleneck is foreseen in the field of cargo information exchange between ports, shipping lines and other logistics operators. The lack of used IT tools in the entire logistics chain definitely hinders the MoS development. This field should be thoroughly analysed, and a detailed action plan appropriate for South East Europe should be prepared shortly.

As far as other bottlenecks are concerned, a severe doubt appears inevitable, as some economies and important companies are significantly depending on road transport and they might lose significant profit from shifting from road to sea or MoS. Consequently, strong resistance to change traditional transport routes and modes is being predicted. For this reason, it is important that the economy and industry recognise long term benefits of MoS implementation.

\section{Main possible routes of MoS}

Possible routes of MoS are developed according to market needs. Capacity utilization is an important element that should be considered. Beside this element the industry should consider also following elements: trade imbalance and variations in demand, competitive situation, state of the market, and types of customers and cargo [16].

Taking into account possible route characteristics different studies proposed a range of MoS corridors for South East Mediterranean and the Adriatic Sea. A study carried out for the "East Med MoS Master Plan" [17] funded by the 
European Commission - DG TREN proposed nine main MoS corridors. Five corridors are important for the cargo flow in the Adriatic Sea. These corridors are: Igoumenitsa-Koper, Venice(Igoumenitsa)-Patra-(Korinthos), Igoumenitsa-Ancona-Koper, Venice-Koper-Ploce and Malta-Venice.

Just three MoS corridors include ports on the eastern coast of the Adriatic Sea. In all three corridors Koper port plays an important role. Meanwhile, from a range of other ports just port of Ploce is proposed for the line with Venice port.

The Corridor Igoumenitsa-Koper should be an alternative to the strong road transport between south Europe and central Europe. Markets as Hungary, Austria and other central European countries should shift an important part of a daily truck line to the MoS. A yearly traffic of 400000 to 600000 tons has been foreseen till the year 2015. This MoS corridor organized by RO-RO service should be an alternative to the existing X. Pan-European Corridor and should use V. Pan-European Corridor to link Koper port with the hinterland destinations by rail, as already almost $70 \%$ of all cargo is transported from the port by rail.

The described MoS corridor will face troubles to attract significant cargo flow, because the length of the journey from Greece to Slovenia via X. Pan-European Corridor is approximately $1450 \mathrm{~km}$. It can be foreseen that only one third of the actual road transport might be transferred to MoS service. Consequently, the total annually shifted traffic could reach up to 600 million ton $/ \mathrm{km}$.

The second proposed corridor Igoumenitsa-Ancona-Koper is almost the same corridor as the previous one, but important cargo flow from central part of Italy should be collected by RO-RO service for central Europe, the Balkans, and for the western part of Greece. The study "East Med MoS Master Plan" shows that from Ancona to Koper and vice versa over 2 million tons of goods should be shifted to MoS by 2015 . Main countries interested in such service should be Slovenia, Croatia and Hungary, as they have strong import and export goods flow with the central part of Italy.

The MoS corridor Venice-Koper-Ploce should be mainly established to connect the northern and central part of Italy to the Balkans, especially markets of Croatia and Serbia. With this RO-RO service around 800000 to 1.3 million tons of goods might be shifted from roads to the sea. This corridor might also experience troubles with shifting significant cargo flow and passengers to MoS service, because the distance by road between northern Italy and Croatia is just 500 to $600 \mathrm{~km}$, and these markets are connected mainly by highways.

Beside the proposed MoS corridors, an important corridor should be additionally supported in the future. It is the RO-RO service between northern Adriatic ports (Trieste or Koper) with Albania and its port in Durres. Durres port is situated on important VIII. Pan-European Corridor and directly connects markets of FYR Macedonia, Bulgaria, Romania, Serbia and partly Greece. Although Albania is not an EU country the service should be seen as an important European intermodal link, which should offer and gain important benefits from modal shift.

\section{THE CASE STUDY OF THE ADRIATIC SEA REGION}

The case study performed on the Adriatic Sea region concentrates mainly on the eastern coast of the Adriatic Sea. A lot of bottlenecks have been foreseen by different authors, therefore a complete analyse of all main key elements influencing the MoS development is necessary. Consequently, all main ports were analysed and compared, including the actually used infrastructure and IT tools or programs used by terminal operators. In addition, the inland infrastructure and hinterland terminals were analysed to formulate a strategy of faster MoS development in the Eastern Mediterranean and in the Adriatic Sea. Moreover, it becomes very important to set up a macro strategy for MoS development for a longer period, in order to attract financial support from the private sector.

\section{Port infrastructure and superstructure}

Port systems are one of the important elements in MoS development. They should cut down all waste operations, extra costs on door-to-door transportation, and perform lean modal shift. Problems of agile port operations have been deeply analysed and discussed by Vis and de Koster [18], Steenken et al. [19], and Notteboom et al. [20]. Paixao and Marlow [21] propose that ports must adopt a completely new logistic approach and agility to cope with new trends on the global market.

It has been realised that there exist big differences between the ports and their terminals in sense of technical equipment, handling capacities and infrastructure. But it is valid for all these marine systems that are faced with more and more intermodal units to be handled in short time and at low cost. It is essential for operators to reduce unproductive time and to offer effective processes in order to be in line with constantly increasing competition among ports or terminals.

According to the research of all main ports on the eastern coast of the Adriatic Sea, the infrastructure and superstructure is very poor. All maritime ports, except Koper and Piraeus, are underdeveloped on the sea side as well as on the land side. The dedicated intermodal infrastructure practically does not exist. In Tab. 1 basic infrastructure data for container and RO-RO terminals were collected. The data for Piraeus port were not included as this port is not representative due to well developed infrastructure and important role for containerised and RO-RO traffic in the Mediterranean.

All five analysed ports together have just 10 specialised RO-RO ramps. In most cases, the quay or berths for RO-RO and container vessel are the same. Among these ports only Koper has suitable infrastructure to support efficient MoS services. Other ports can also be a gateway for MoS, but their infrastructure and superstructure cannot assure efficient modal shift which MoS should offer to the cargo owners. Beside the infrastructure, the superstructure of the maritime ports is also superannuated and actually cannot support higher volumes of intermodal cargo. Ports as Ploce, Bar and Durres do not have specialised container berth cranes. Almost the same situation is on the yard, where container gantry cranes are not in use. All handlings of intermodal units are performed by reachstakers or forklifts.

Tab. 1. Basic port infrastructure data for container and RO-RO terminals

\begin{tabular}{|c|c|c|c|c|}
\hline Port & $\begin{array}{c}\text { Quay length } \\
{[\mathbf{m}]}\end{array}$ & $\begin{array}{c}\text { Draught } \\
{[\mathbf{m}]}\end{array}$ & $\begin{array}{c}\text { RO-RO } \\
\text { ramps }\end{array}$ & $\begin{array}{c}\text { Yard capacity } \\
{[\mathbf{m}]}\end{array}$ \\
\hline Bar & 770 & 12 & 1 & 65000 \\
\hline Durres & 700 & 10 & 4 & 30000 \\
\hline Koper & 1400 & 11.4 & 4 & 1135000 \\
\hline Ploce & 300 & 13.8 & 1 & 38000 \\
\hline Rijeka & 460 & 11 & 0 & 135500 \\
\hline
\end{tabular}

Moreover, it has to be jeopardising that in the South East Europe region there are no functioning modern hinterland intermodal terminals. This has been acknowledged also by 
Šakalys and Palšatis [22], as they came to the conclusion that a very small quantity of inland terminals exist in Southern and Eastern Europe, and they operate with limited handling equipment and on limited land area. The only operating railway stations that can accommodate containers and other intermodal units are situated in capital cities such as Belgrade, Zagreb, Ljubljana, Sarajevo, etc. These terminals do not use modern handling technologies, the degree of automation is very low, and static and dynamic capacities cannot secure optimal handling processes.

Obviously the actual port infrastructure and superstructure on the eastern coast of the Adriatic Sea is not in a position to fulfil all key elements of MoS development. On the one hand, port systems cannot be cost effective, and on the other, they cannot maintain requested service schedules and so important transit times. The reliability of such MoS would be under a big question.

\section{Inland connections and infrastructure}

Intermodal transport and appropriate infrastructure is an important element of MoS development. It can be expressed as a basic platform to develop MoS, and it is directly linked with the health of the regional economy. Stronger economy uses intermodal transport advantages in order to achieve stronger long-term development. Consequently, such economies are directly investing in intermodal infrastructure. The comparison between Western European infrastructure with South Eastern one shows that the last one is underdeveloped and superannuates.

The difference is not as big in road infrastructure as it is in railways. States of South East Europe invested in highways development between the capital cities. Highway connections with the maritime ports are practically nonexistent, except Koper port and to some extent the ports of Rijeka and Durres.

The MoS for the South East Europe should be developed with connection to the rail transport. The railway should be used as the key transport solution between maritime terminals and hinterland hub terminals. Consequently, the road transport should be used only on shorter transport routes up to $150 \mathrm{~km}$ and on direct to door deliveries. Unfortunately, the use of the rail transport in South East Europe drastically decreased in the last decade, and at the same time the railway infrastructure was not modernised accordingly. As shown in Tab. 2, the total length of railway lines in South East Europe is $13276 \mathrm{~km}$ and was reduced by over $200 \mathrm{~km}$ in the analysed countries. Meanwhile, in the same period Western Europe increased them, especially in Spain and Germany.

The length of the road network in South East Europe is about $182600 \mathrm{~km}$. Just $3910 \mathrm{~km}$ or $2.14 \%$ of all road networks are highways, where just Greece and Croatia are above this low average. Consequently, it can be stressed out that such an infrastructure does not allow high transport speed and cannot secure high security standards.

Beside the fact that the road network is not developed and does not permit high transport speed, it must be accentuated that the rail network is even more superannuated. As analysed in Tab. 3, on an average the rail network represents just 6.8\% of total inland transport network. Furthermore, the railway transport speed is in average below $40 \mathrm{~km} / \mathrm{h}$, in some sections even below $20 \mathrm{~km} / \mathrm{h}$.

The analysis can be summarized that inland connections are not supporting modern logistics concepts. This can have positive and negative impacts on the development of MoS.

Tab. 2. Total length of railway lines $(\mathrm{km})[23]$

\begin{tabular}{|c|c|c|c|c|c|c|c|c|c|}
\hline & $\mathbf{2 0 0 1}$ & $\mathbf{2 0 0 2}$ & $\mathbf{2 0 0 3}$ & $\mathbf{2 0 0 4}$ & $\mathbf{2 0 0 5}$ & $\mathbf{2 0 0 6}$ & $\mathbf{2 0 0 7}$ & $\mathbf{2 0 0 8}$ & $\mathbf{2 0 0 8 / 2 0 0 1}$ \\
\hline Belgium & 3454 & 3518 & 3521 & 3536 & 3544 & 3560 & 3568 & 3513 & 101.7 \\
\hline Czech Rep. & 9523 & 9600 & 9602 & 9612 & 9614 & 9597 & 9588 & 9586 & 100.6 \\
\hline Germany & 35986 & 35803 & 41531 & - & 38206 & - & 41209 & 37798 & 105.1 \\
\hline Spain & 12310 & 12298 & - & 12873 & 12839 & 13008 & 13368 & 13353 & 108.5 \\
\hline Sweden & 11021 & 11095 & 11037 & 11050 & 11017 & 11020 & 10972 & 11022 & 100 \\
\hline Netherlands & 2809 & 2806 & 2811 & 2811 & 5231 & 2797 & 2801 & 2888 & 102.8 \\
\hline Slovenia & 1228 & 1228 & 1228 & 1228 & 1228 & 1228 & 1228 & 1228 & 100 \\
\hline Croatia & 2726 & 2726 & 2726 & 2726 & 2726 & 2722 & 2722 & 2722 & 99.8 \\
\hline Macedonia & 699 & 699 & - & 699 & 699 & 699 & 699 & 699 & 100 \\
\hline Bulgaria & 4320 & 4317 & 4316 & 4259 & 4154 & 4146 & 4143 & 4144 & 95.9 \\
\hline Romania & 11015 & 11002 & - & 11053 & 10948 & 10789 & 10777 & 10785 & 97.9 \\
\hline Greece & 2377 & 2383 & 2414 & 2449 & 2576 & 2509 & 2551 & 2552 & 107.4 \\
\hline
\end{tabular}

Tab. 3. Total length of roads and railway lines in South East Europe

\begin{tabular}{|c|c|c|c|c|c|}
\hline & $\begin{array}{c}\text { Roads } \\
{[\mathbf{k m}]}\end{array}$ & $\begin{array}{c}\text { Highways } \\
{[\mathbf{k m}]}\end{array}$ & $\begin{array}{c}\text { Roads/Highways } \\
{[\% \mathbf{\%}]}\end{array}$ & $\begin{array}{c}\text { Rail } \\
{[\mathbf{k m}]}\end{array}$ & $\begin{array}{c}\text { Road/rail } \\
{[\%]}\end{array}$ \\
\hline Albania & 18000 & 170 & 0.94 & 447 & 2.48 \\
\hline Bosnia\&Her. & 22900 & 0 & 0.00 & 1031 & 4.50 \\
\hline Croatia & 28400 & 1340 & 4.72 & 2722 & 9.58 \\
\hline Greece & 17000 & 1030 & 6.06 & 2552 & 15.01 \\
\hline Macedonia & 9570 & 190 & 1.99 & 699 & 7.30 \\
\hline Montenegro & 5174 & 0 & 0.00 & 250 & 4.83 \\
\hline Serbia & 42690 & 560 & 1.31 & 4347 & 10.18 \\
\hline Slovenia & 38873 & 620 & 1.59 & 1228 & 3.16 \\
\hline
\end{tabular}


On the one hand, superannuated inland infrastructure calls for $\mathrm{MoS}$, in order to shift cargo from inland transport to potentially better and faster sea transport. On the other hand, inland transport infrastructure is in worse conditions close to the ports, as some of them are still not connected with the highways. Consequently, road door-to-door services are preferred.

\section{IT systems and documentation procedures}

Modern information technologies and systems are very important tools to enhance the integration of intermodal operations and to speed up the modal shift at intermodal points. Efficient data exchanges between all logistics operators and cargo owners are especially important to establish just one IT data network, with uniformed quantity and quality of information flow. European Union and European Commission recognised this important goal a decade or two ago. The main aim is to support research which addresses practical problems of implementing the latest information technologies in intermodal logistic organisation, and help to break barriers by introducing cutting-edge technologies to the system, standards and services [24].

Different EU projects analysed actual needs of the industry to work in a real-time logistics information network. Important projects were INTRARTIP, MARNET, ITESIC, INFOLOG, etc, which provided proposals for full information network architecture, consisting of a uniformed information platform and standardised solutions to integrate Electronic Data Interchange (EDI) in the entire logistics chain. Services like $\mathrm{MoS}$ need up-to-date booking services, tracking and tracing management, paperless working processes, simplified administrative services, etc.

Unfortunately, ports and hinterland terminals do not use uniformed IT systems, which should be easily connected through standardised information platform. Among the analysed ports and terminals only ports of Koper and Piraeus have integrated an EDI system that to some extent simplifies information exchange between shipping lines, ports and the inland transport operator. Ports of Rijeka, Ploce, Bar and Durres do not use modern IT platforms to simplify data exchange between logistics providers. Moreover, in Durres port all the procedures and direct orders to the port are still managed through hard copy documents, which can be hand over manually or as scanned documents by e-mail system. The same procedure is in practice also with other authorities as customs, phytosanitary inspections, police etc.

IT communication is one of the key elements influencing MoS development, and the present situation in the ports and hinterland terminals in South East Europe is not satisfactory for fast MoS development. A two-pillar action plan should be made in a short time to remove the barriers of interoperability between different information systems. Firstly, ports must integrate an EDI practice in their processes, even if they are inhomogeneous with other operators. And secondly, a centralised communication node should be developed. Such a node should connect and integrate shipping lines, their agents, logistics providers, forwarders and cargo owners into a main 'umbrella' module. Consequently, an IT platform should be successfully implemented, improving cargo information exchange and securing on-line cargo tracing and tracking. Thus, the needs and expectations from MoS should be provided.

\section{A need for macro transport strategy}

Based on the described findings, it is necessary that the region of South East Europe makes a common strategy on developing intermodality in the region and on how MoS should be developed in a long term. According to the research, a short-term strategy would not bring necessary actions to actively develop MoS in the Balkans. In this situation two approaches are possible - a bottom-up or a top-down approach. Rodrigue et al. [25] says that with a top-down approach direct and fast actions can be implemented, but these actions should be executed by the governments or Port authorities. These actions should not be focused on road charges only as they may not achieve the desired shift from road to sea operations, particularly in countries where the economic and social impacts of road freight movement outweigh its external impacts and costs [26].

Parantainen and Merilainen [27] say that a bottom-up approach is the best way of developing concrete projects. Projects should be based on realistic estimates of transport volumes and create permanent and economically feasible transport chains. This is also valid for MoS, because the development of MoS should be done on a project base. It can be anticipated that with the bottom-up approach the industry can efficiently enter the sector of intermodality and modal shift. With such approach, the industry must present its expectations and needs to governmental institutions and dynamically cocreate a macro transport development strategy in the region. With this it is possible to influence governmental investments in transport infrastructure and future legislation in the transport sector. The industry must press the Port authorities to introduce EDI platforms and to reduce documentation processes in business cooperation with the ports and hinterland terminals. Clark et al. [28] expose that legal restrictions can negatively affect port performance and the transport system as a whole. Thus, the industry must be active also in this very important field of transport regulation.

Given the analysed infrastructure, superstructure, and current data exchange procedures in South East Europe it is necessary to develop a long-term transport policy for this European region. With a macro transport strategy an innovative environment should be established. According to Haralambous [5], the intermodal chain must provide free flow without any bottlenecks, physical or operational, and has to be a credible choice. The concentration on cargo flow is recommended to ensure viability, but also the promotion of ports from Maritime transport servers to intermodal nodal points that provide fast and low cost services, and optimum connections to land high level infrastructure are prerequisites for the success.

Therefore, the MoS development mainly has to focus on infrastructure modernization to stimulate intermodality and, at the same time, the key elements and goals of modern, lean and green logistics should be considered accordingly.

\section{CONCLUSION}

The MoS initiative is an important goal supported and coordinated by the European Commission. The main goal is to reduce congestion on European roads, to shift cargo and passengers from land transport to the sea, to reduce external costs from the extent use of road transport, and to achieve long-term economic growth in the Community. Based on the above, the MoS concept has been promoted as an intracommunity strategy, with special emphasis on ports, their infrastructure and hinterland connections, especially railway network connections.

The MoS are very important "tools" also for the region of South East Europe. Global companies recognised Eastern Europe as an important alternative for Far East production. But investments in massive manufacturing need a support 
from the transport sector, in order to secure "just in time" and "just in sequence" production and distribution. The MoS can significantly support increased cargo flows of raw materials in import and finished product in export from the Balkans, but also need modernised port infrastructure as well as inland connections.

The situation in South East Europe, especially in the Balkans, does not offer a short-term solution for massive MoS implementation. Firstly, the economy is very poor, especially in the era of global crisis. Secondly, the transport infrastructure and superstructure is superannuated, and without actual funds it is impossible to realise important investments, neither by the states nor private sector.

The only adequate intermodal points are the ports of Koper and Piraeus, which invested in infrastructure and superstructure during the last decades. These ports can be an important gateway for MoS. Although they are well equipped and organised, the main bottleneck remains the inland connection by rail. Port of Koper is suffering from congestion on the rail transport, as over $70 \%$ of goods are transported from the port by rail. Other ports as Rijeka, Ploce, Bar and Durres do not have adequate infrastructure to importantly support MoS. Their main problem is also that they do not use uniformed IT systems, which should connect shipping lines, shipping agents, forwarders and other operators in a unique IT chain.

Undoubtedly, the MoS have a future in South East Europe and in the Adriatic Sea. But it is necessary to develop a longterm transport policy for this European region to further analyse all described bottlenecks, in order to remove them shortly. In this way, a private sector should be importantly stimulated for direct financial investments. Consequently, a bottom-up approach of MoS development should be established. According to the past experience with MoS implementation, this is the only appropriate way to have long active MoS services.

\section{BIBLIOGRAPHY}

1. Paixao A.C.: Motorway of the sea port requirements: the viewpoint of port authorities. International Journal of Logistics: Research and Applications, Vol. 11, No. 4, 2008, p. 279-294.

2. Bagchus R.C. and Kuipers, B.: Autoestrada del Mare. In: European ShortSea Shipping, Proceedings from the First European Research Round Table Conference on Short Sea Shipping,London, England, 1993.

3. Psaraftis H.N.: EU Ports Policy: Where Do We Go from Here? Maritime Economics \& Logistics Vol. 7, 2005, p. 73-82.

4. Baird A.J.: Investigating the feasibility of fast sea transport services. Maritime Economics \& Logistics, Vol. 6, 2004, p. 252-269.

5. Haralambous G.: The contribution of the "Sea Motorways" to the European transport Policy. European Conference of Transport Research Institutes - YRS05, Hague, 2005.

6. Tilling C.: The EU common transport policy for south-east Europe - what makes it a factor of cohesion and sustainability? South East Europe Review, Dusseldorf, 2006.

7. European Commission: Priority projects for the trans-European transport network up to 2020. High-Level group report, Luxembourg, 2003.

8. Midelfart-Knarvik K.H., Overman H.G., Redding S.J., Venables A.J.: The Location of European Industry. Economic Papers Number 142. Luxembourg, 2000.

9. Baird A. J.: The Economics of Motorways of the Sea. Maritime Policy Management, Vol. 34, No. 4, 2007, p. 287-310.
10.Napier University \& Partners: UKMM - United Kingdom Marine Motorways Study, Future Integrated transport (FIT) Link Programme. Department for Transport and Engineering \& Physical Science Research Council (EPSRC), Edinburgh, 2002.

11.Shinghal N. and Fowkes T.: Freight mode choice and adaptive stated preferences. Transport Research Part E, Vol. 38, 2002, p. 367-378.

12.Ng A.K.Y.: Competitiveness of short sea shipping and the role of port: the case of North Europe. Maritime Policy \& Management, Vol. 36, No. 4, 2009, p. 337-352.

13.Paulauskas V. and Bentzen K.: Sea Motorways as a Part of the Logistics Chain. Transport, Vol. 23, No. 3, 2008, p. 202-207.

14.Trujillo L. and Medda F.: Road Freight Market Distortion and the Viability of SSS. Second annual conference on competition and regulation in network industries, Brussels, 2009.

15.Paraschiv D.M., Popa I., Caragin A.R., Tartavuela R.I.: Evolution of Strategic Supply Chain in Central and Eastern Europe in Turbulent Times - Focus Romania. The 8th International Conference on Logistics and SCM Research, Bordeaux, 2010.

16.Styhre L.: Strategies of capacity utilisation in short sea shipping. Maritime Economics \& Logistics, Vol. 11, No. 4, 2009, p. 418-438.

17.European Commission: Elaboration of the East Mediterranean Motorways of the Sea master plan. East Mediterranean master plan of the Motorways of the Sea, Brusels, 2009.

18.Vis I.F.A. and De Koster R.: Transvesselment of Containers at a Container Terminal: an Overview. European Journal of Operational Research, Vol. 147, No. 1, 2003, p. 1-16.

19.Steenken D., Voss S., Stahlbock R.: Container Terminal Operation and Operation Research - a Classification and Literature Review. OR Spectrum, No. 26, 2004, pp 3-49.

20.Notteboom T.E. and Rodrigue J.P.: Port Regionalization: Towards a New Phase in Port Development. Maritime Policy and Management, Vol. 32, No. 3, 2005, p. 297-313.

21.Paixao A. C. and Marlow P. B.: Fourth generation ports-a question on an agility?. International Journal of Physical Distribution and Logistics Management, Vol. 33, No. 4, 2003, p. 335-376.

22.Šakalys A. and Palšatis R.: Development of intermodal transport in new European Union states. Transport, Vol. 21, No. 2, 2006, p. $148-153$.

23.Eurostat, 2010, http://appsso.eurostat.ec.europa.eu/nui/show. do?dataset=rail_if_tracks\&lang=en

24.European Commission: Motorways of the Sea-Modernising European Short Sea Shipping Links. Luxembourg, 2006.

25.Rodrigue J. P., Slack B., Comtois C.: Green Logistics (The Paradoxes of). in: Brewer A.; Button, K.; Hensher, D. The handbook of Logistics and supply-chain management, London, 2001.

26.Medda T. and Trujillo L.: Short-sea shipping: an analysis of its determinants. Maritime Policy \& Management, Vol. 37, No. 3, 2010, p. 285-303.

27.Paratainen J. and Merilainen A.: The Baltic Sea Motorway - Recent Development and Outlook for the Future, Journal of Maritime Research, Vol. 4, No. 2, 2007, p. 21-30.

28.Clark X., Dollar D., Micco A.: Port efficiency, maritime transport costs, and bilateral trade. Journal of Development Economics, Vol. 75, 2004, p. 417-450.

\section{CONTACT WITH THE AUTHOR}

Bojan Beškovnik, Ph.D.

Intereuropa, Global logistics service, Ltd. Co. Vojkovo nabrežje 32,

SI-6000 Koper, SLOVENIJA

e-mail: bojan.beskovnik@intereuropa.si 